\title{
Study on the Integration of Theory and Practice in the Teaching Mode of Digital Media Art Major in Colleges and Universities
}

\author{
Lu Dong ${ }^{1, a,}$, Robert Willey ${ }^{2, b}$ \\ ${ }^{1}$ School of Mechatronics Engineering, Harbin Institute of Technology, Harbin 150001, China \\ ${ }^{2}$ School of Music, Ball State University, Muncie 47306, USA \\ ad1617@hit.edu.cn, brkwilley@bsu.edu \\ *corresponding author
}

Keywords: Colleges and Universities; Digital Media Art Major; Integration; Teaching Mode.

\begin{abstract}
Digital media art major greatly focuses on combining theory and practice, serving as an organic integration of the two aspects. At present, in China's digital media art teaching, it commonly exists phenomena that the proportion of the collocation of theory and practice is not scientific and reasonable enough, along with the lack of combination of art and technology, moreover. It fails to reflect teaching practice and motivate the subjectivity of students. In order to effectively work out these problems, the author combined with own experience and feelings in foreign universities, putting forward the possibility to build a digital media art major integrated teaching model combined with theory and practice. In this paper, on the basis of a brief presentation of the connotation and advantages of the integration, it mainly focuses on the construction of the integrated teaching mode combining theory and practice in digital media art major.
\end{abstract}

\section{Introduction}

With the accelerated development of economy and the continuous progress of the society, all walks of life need more practical and innovative talents. As an important base for training talents, colleges and universities should shoulder the crucial task of cultivation. The digital media art major in colleges and universities is a young professional which caters closely to the social development. At present, the teaching mode in Chinese colleges and universities is still in the exploratory period, combined with obvious problems such as insufficient correspondence in the current teaching theory and practice. Therefore, it is of great practical significance to study on the integrated teaching mode combining theory and practice in digital media arts in colleges and universities.

\section{Connotation and Advantages of the Integration of Theory and Practice}

The integration of theory and practice refers to the effective combination of theory and practice in modern teaching mode which accords with the cognitive law of students and plays an crucial role in the formation of skills. This kind of teaching mode requires teachers to adhere to the principle "Necessary, Adequate, Suitable and Proper" in teaching; and stresses the normalization, innovation and science of the operation in skills training in teaching methods, teachers should take training as the core, adding theoretical teaching knowledge and using theory to guide practice, thus to verify theory and ensure that the two aspects run at the same time, finally deepen the learners' mastery of knowledge and skills.

The advantages are mainly reflect in: first, it mobilizes the subjective initiative of students, and foster their comprehensive ability to analysis and work out problems; second, it effectively combines classroom with practice, melting the practice skills into teaching to enhance students' practical ability; third, it does help to promote students to transfer the theory into practice, thus develop their innovation and train their practical capacity. 


\section{The Establishment of the Integration of Theory and Practice of the Teaching Mode in Digital Media Art Major in Colleges and Universities}

When the integrated teaching mode established, these aspects below should be taken into consideration.

\subsection{Optimizing and Integrating Professional Courses, Improving the Proportion of Theory and Curriculum}

When carrying out practical courses, it should take the development of students' innovation as the core, thus follow the law of cognitive development and adhere to the principle of "Necessary, Adequate, Suitable and Proper". First of all, internship and practical training can be added in certain curriculum, thus, with reverse consideration, the related theory can be put into practical course to make explaination, which will help students better understand the curriculum; secondly, it is necessary to attach more importance to the cohesion and integration of the following courses, in order to avoid duplication which shall lead to confusion of knowledge and waste of resources. Specific practices are as follows:

First, according to their own interests and expertise, students can develop learning plans and development program. Finally, they can determine a major as a main learning objective.

Second, the module courses all have been divided into theoretical and practical courses, also, compulsory course and selective course have been set up. No matter what the students choose as final professional, these required courses are compulsory; while selective courses are more flexible, students can choose their favorite courses according to their own interests and hobbies. This kind of arrangement will help to improve their interest in learning and develop more professional qualities.

Third, each module has corresponding course hours and credits, students must achieve the required credits of the previous course, thus he can continue to choose the follow-up courses.

\subsection{Establishing Practical Teaching Plan, Developing School-based Teaching Materials}

First, practical teaching plan should be compiled. Colleges and universities can classify part of curriculum into the teaching scope with the "integration of theory and practice", according to the teachers' ability, the quality of students, the number of teaching equipment and the regional characteristics, teaching plans should be compiled with the specific characteristics of the school. If the condition allows, school can divide the teaching contents into several modules, determining the teaching hours of each module. Moreover, a professional direction of the course can be divided into many modules, and each of them has plenty of sub modules which are all closely linked.

Second, teaching materials integrated with the "theory and practice "and internship should be compiled. Based on the adjusted teaching plan and the existing theory and practice, it should adhere to the concept "ability as the core, task as the power", and in accordance to the integrated teaching mode and the demands in development, specialized teaching materials should be compiled, whose contents should include several modules greatly selected, furthermore, the practical principle should be adhered, the theoretical knowledge related to practice should be emphasized, the students' practical ability should be mainly cultivated and the practical operational capacity should also be enhanced.

\subsection{Designing Core Teaching Content, Highlighting Main Practice of Students}

The teaching system combined with theoretical and practical teaching should be constructed at the same time with equal importance. Digital media arts curriculum includes two learning objectives --technical operation and artistic expression, each contains many learning modules, thus teachers should design the corresponding theoretical and practical learning tasks in the learning module, interspersed with fresh or classic cases during the explanation in order to facilitate the students to understand and accept them.

For example, the "Sound Media" module starts from the theory and practice course along with compulsory and elective courses, setting up courses as follows: Basic Theory of Music, History of Sound Media, Music Culture Theory, Sound Media Industry and Modern Computer Audio 
Technology, Audio Recording Technology, Software Engineering Learning and Works Designing, Sound Mixing Technology, Project Practice, etc. At present, the competition in employment of college students is becoming more fierce and intense, in order to let the graduates have more choices, universities must adhere to the premise of "Thick foundation, Wide caliber", thus specialize contents and implement module teaching to lay a solid and professional basis for students, preserving students to "be excel in skills and specialized in professionals", also, it will help students to master specialized knowledge and skills under digital media arts and enhance the competitiveness of graduates. What's more, Increasing the intensity of training students' practical ability will definitely realize the transition from theory to practice; the ideological education will help students to form correct values, to cultivate their favorable occupation morals; also, colleges should foster their self-learning capacity, observation, thinking and operation ability, and also cultivate professional literacy of students such as honesty and win-win cooperation.

\subsection{Integrating Reasonably the Modern Network Resources and Highlighting the Innovation of Teaching Process}

The curriculum should take project or task as carrier, through the organic combination of teachers and students' presentations and demonstrations along with the interaction between them, to make "teaching" and "learning process" operate at the same time, thus to achieve the integration of theory and practice. Combined with the requirements of the industrial society to the graduates, it should improve the students' adaptive capacity for the future occupations.

In the process of teaching, teachers can apply multimedia teaching equipment, professional hardware and software, relevant audio, video, and network teaching resources, to equip students with the ability to fully understand and grasp the link between professional theoretical knowledge and operation procedure. The teaching course of digital media art major can make the Micro Learning Resource to be fully utilized, which is greatly helpful to cultivate students' self-learning ability and make the study purposes clearer. The colleges and universities which have completely constructed the training base should make full use of such advantage to implement on-site teaching practice, so that students can participate in the whole project design and promote the realization of the integration.

\section{Epilogue}

Digital media art major integrates theory and professional knowledge, technical operation and artistic creation, closely linked with social emerging industries, which requires that the students should not only be equipped with solid professional basis, but also a certain art foundation, should not only have great practical ability ,but also fully understand the market and industrial demand, in order to cultivate more talents of digital media art with excellent professional qualities, universities should attach great importance to the reform and innovation of teaching mode in digital media art and polish the students to be specialized in skills and make study serve the practical purpose. Only in this way can digital media art achieve better development.

\section{References}

[1] Zhang Kun. Research on the rationality of the digital media art major setting in colleges and universities in Jiangsu [D]. Nanjing Arts Institute, 2014

[2] Liu Juemin. Study on the balanced development in the training mode of digital media art talents in higher vocational colleges in Jiangsu [D]. Nanjing Arts Institute, 2013

[3] Li PengJie. Study on the current situation and teaching system of digital media art in colleges and universities [D]. Hebei Normal University, 2010 
[4] Huang Zhuo. Fundamental study on the transformation of digital media art major: insisting on the design art education based on humanism [J]. Journal of Liaoning Vocational Economics College (Journal of Liaoning Economics and Management College), 2008, (107+109.) 